\title{
Entrevista com Arlindo Machado \\ O processo de recepção e as novas tecnologias de comunicação
}

NO - Como interpretar, na discussão teórica atual, novos media, como a Internet?

AM - Acho que ela é ainda um universo potencial de distribuição a ser inventado. A Internet, para mim, não é uma mídia, ainda não se configura como a televisão, o cinema, o rádio, que são modos de organização da informação, do pensamento, quer dizer, têm seus gêneros próprios, seus modos de ficção próprios, suas formas de veiculação da informação próprias. A Internet é um sistema de distribuição, por enquanto. É um gigantesco sistema de distribuição que está gerando suas próprias mídias. Nós estamos vendo nascer dentro da Internet meios específicos como, por exemplo, as comunidades virtuais, que são estes sites no ciberespaço, lugares onde as pessoas se encontram virtualmente, lugares que não existem. Nós poderíamos estar reunidos no ciberespaço, em vez de estarmos aqui fisicamente. Alguém poderia fazer uma interface, cada um teria um boneco se representando, estes bonecos sentariam na mesa e a gente ficaria assistindo, no monitor, um debate do qual nós estaríamos participando, seja através de texto ou através de voz. São mídias que estão nascendo, estão se desenvolvendo. Ainda são muito precárias mas têm um potencial gigantesco de expansão. Acho que a coisa mais interessante é que são mídias novas que tiram, de certa forma, aquele caráter passivo do espectador, são mídias que exigem um novo tipo de postura do agente dentro dele, você não é mais alguém que está vendo algo que foi feito para ser contemplado, mas é alguém que tem potencial de transformar aquilo que está acontecendo. Você entra na Internet e o que vai acontecer é em função do que você faz, de decisões que você toma. Ou seja, você tem uma posição ativa com relação aquilo que está acontecendo. Nós poderíamos estar reunidos virtualmente e a reunião não está decidida, não é algo que alguém arquitetou, será em função do que cada um de nós vai dizer.

NO_Como é que o senhor analisa a televisão diante desta nova possibilidade mediática?

AM - Eu acho que a televisão é o meio que mais vai sofrer transformações dentro de um futuro bastante próximo. Isso os próprios magnatas e estrategistas da TV estão se antecipando, investindo dinheiro nestas novas tecnologias, porque eles sabem que a televisão, tal como ela existe, vai sofrer transformações violentas dentro de um tempo bastante próximo. Essas mudanças dizem respeito a uma série de coisas. Primeiro, à alteração do próprio conceito de programa, e de envolvimento do telespectador. À medida que a televisão for migrando para a Internet -nós não sabemos se a televisão vai migrar para Internet ou se a Internet vai migrar para a televisão -, as duas coisas tendem a juntar-se e misturar-se. A televisão e o computador não serão coisas diferentes. Eu não sei se a gente vai assistir televisão no computador ou se a Internet 
vai ser acessada pela televisão, ou -o que é mais provável- se as duas coisas vão acontecer simultaneamente.

A tendência é haver uma fusão cada vez maior entre essas duas coisas e aí, temos conseqüências bastante importantes, por exemplo: toda a idéia de programação vai ser alterada. O espectador não vai ser mais espectador, terá um novo nome, nós teremos de inventar um novo nome para ele, que não é mais alguém que fica "espectando" - que vem do latim spectare, que quer dizer olhar -, é alguém que tem papel ativo, ele vai tomar decisões, as coisas vão acontecer muito em função do que ele faz. Isto é discutível, claro. As decisões que este novo agente pode tomar são decisões que estão dentro de um marco previsto: o que pode ser feito é porque foi previsto que pudesse ser feito. Não se pode fazer qualquer coisa se essa coisa não está prevista no próprio programa.

De qualquer forma, esse sujeito que vai se defrontar com a programação, ele é quem toma as decisões, ou seja, não existem mais programas específicos para determinados horários. Tudo está lá. $\mathrm{O}$ sujeito, quando entra na Globo, por exemplo, tem toda a programação da Globo ali, e decide o que quer ver. Não tem mais jornal das oito, novela das sete, você tem tudo ali. Não só a programação do dia, mas também dos dias anteriores, provavelmente. Se você perdeu vários capítulos de novela, e quiser ver, você pode ver os capítulos em uma ordem diferente. Eu posso ver a televisão de uma maneira que eu programo, e não da maneira que foi programada pela própria rede. Isto traz conseqüências, dá um poder maior ao telespectador, que vai ver o que quer.

Eu acho que a postura atual do telespectador é muito passiva ainda, extremamente passiva. As pessoas chegam em casa cansadas, ligam a televisão, e seja lá o que for que estiver passando, elas vêem. Na verdade, não importa muito o que está passando, desde que distraia um pouco, a pessoa não está preocupada com o que está vendo. Dentro de pouco tempo não vai haver nada disso. Você vai chegar, ligar a televisão, e não vai acontecer nada. A televisão fica só ligada, aquela coisa azul, ou fica um menu na sua frente, como em um computador que você liga, entra na Internet e não acontece nada, você só entrou. Aí, tem uma página inicial, que dá uma série de possibilidades, mas se você não escolher nada, não sai daquilo. Então você tem que estar sempre tomando decisões: eu quero ver isto, r eu quero ver aquilo, e se não está legal, você pode parar de ver, ir ver outras coisas. Se não está legal a novela, vou ver o filme, vou ver o jornal. Então você pode fazer percursos diferentes, e isso, eu acho, que vai criar um espectador mais exigente, mais ativo, com maior capacidade de discriminação, pois a gente não tem que ficar esperando, e não têm de se submeter a decisões que foram tomadas por outros.

NO - Nesse contexto, qual seria a qualidade a ser buscada na TV?

AM - Difícil saber. Mesmo nas formas tradicionais é difícil saber quais as qualidades que a gente busca, imagine então no que vem aí pela frente. Eu sempre digo que a qualidade não é uma coisa fácil de ser definida, é bem mais fácil você definir o que não tem qualidade, dizer por que não tem qualidade. Até porque a qualidade está associada a idéia de criação, de invenção. A qualidade está muito ligada àquilo que não é repetição, que não é o lugar-comum, o esperado. E se algo não é o esperado, é algo que não está pronto, que está sendo inventado. Então, se você define: "qualidade é tal coisa", você fechou, eliminando a possibilidade que alguma coisa seja criada diferente daquilo.

Eu também acho que a qualidade é um resultado de uma discussão coletiva. Isso sempre foi assim, a própria idéia de democracia é assim. O que é liberdade, participação coletiva? $\mathrm{Na}$ verdade, a qualidade é uma discussão coletiva, é 
uma vigilância permanente. Devemos estar permanentemente atentos e denunciando aquilo que a gente acha que não é livre, não é democrático, não é público. Da discussão coletiva a gente vai destilando formas mais avançadas, superiores. Eu acredito que ninguém tenha uma fórmula, aliás, a idéia de qualidade é inteiramente avessa a qualquer fórmula. Não há nenhuma regra que diga: qualidade deve ter isto e "não qualidade" é o que não tem isto, porque aí, você elimina aquilo que é a alma da quali dade, que é a descoberta, a invenção, o surgimento do que ainda não existe, a possibilidade de sair do lugar-comum, de inovar, de criar novas formas de vivência, de emoção, etc.

Eu sempre digo que o que falta é o enfrentamento dessa discussão. O que falta é essa discussão ser iniciada, e essa discussão vai destilando qualidade. Eu sempre cito o caso de Sheakspeare. Sheakspeare tem qualidade ou não tem? Tem gente que diz que não tem, que Sheakspeare é ruim. Mas milhões viram Sheakspeare ao longo da história e milhões chegaram à conclusão que ele é bom. Não é um especialista, um crítico que diz se Sheakspeare é bom ou não. É uma história vivida pela humanidade, que destilou trabalhos que são tão fortes que sobreviveram às críticas, que sobreviveram aos tempos e que até hoje têm coisas a dizer. Mas a qualidade que tem Sheakspeare não é a mesma qualidade que tem Balzac, que tem Bethoveen. São qualidades diferentes, por isso não cabe uma fórmula. Eu acho errado que digam: a televisão de qualidade deveria ser assim ou assado. Ela poderia ser qualquer coisa.

O que vai determinar a televisão de qualidade é um debate coletivo, e é isso que falta. A gente tem que fazer esta discussão, tem que ter o hábito de discutir televisão. Discutir mesmo: os programas, as novelas, os jornais. Não esta discussão anti-televisão, que generaliza de uma tal maneira que na verdade nada é discutido especificamente.
NO - Como o senhor vê a questão do controle social da televisão que se busca hoje no Brasil?

AM - Eu acho bobagem, não é por aí. Eu acho bobagem mas, por outro lado, também devemos considerar o seguinte: a sociedade não pode deixar a televisão fazer o que ela quer. Eu acho que, quando o governo intervém, digamos que ele seja bem intencionado, ele tem atitudes infantis no modo que ele lida com a coisa. Mas eu acho que a sociedade e o i-governo -se pensarmos o governo em um sentido mais amplo, democráticodevem controlar a televisão que, afinal, é uma concessão pública e tem que prestar contas à sociedade. A sociedade deve fazer exigências com relação à televisão, sim, disto eu não tenho dúvida nenhuma. E esta discussão toda que está havendo é uma falsa discussão. Se o governo intervém é censura. Por que é censura? Porque quem controla os meios são os mesmos grupos. Esses grupos não querem ser controlados, não querem nenhum tipo de ingerência sobre eles, nem do governo, nem da sociedade, nem de ninguém. Então, cada vez que o governo vai lá e mexe na ferida eles gritam que isto é censura, é uma forma de autoritarismo $\mathrm{e}$, às vezes, a gente embarca nisso.

Eu acho que os meios de comunicação dominam muito a discussão, e nós, a Universidade, o pensamento científico autônomo, estamos muito sem posições e de certa forma acabamos embarcando em temas que não fomos nós que colocamos. Faz tempo que a Universidade não põe temas para discussão. Nós ficamos discutindo temas que os meios colocam, e os meios de comunicação estão constantemente colocando temas que interessam a eles. Quando eles falam: "Contra a censura!", vai todo mundo, claro, contra a censura. Quem não é contra a censura? Nós passamos tanto tempo lutando contra a censura, na época da ditadura. Mas "contra a censura" pode simplesmente significar: "então as redes de televisão podem 
fazer o que quiserem, elas são donas do espaço eletromagnético, elas não têm de prestar contas à sociedade, a sociedade não pode intervir no que elas fazem". Eu não acho que isto seja correto. A sociedade tem que impor restrições, limites. A questão agora é discutir quem tem legitimidade para dizer o que se pode fazer e o que não se pode. A sociedade tem que restringir sim a liberdade das emissoras, porque as próprias emissoras produzem censura interna, elas põem o que elas querem no ar, tiram Por fim, o que eu acho que falta para a o que querem do ar, e eu não vejo nin- gente é, de um lado, essa discussão guém se mobilizando quando a Rede Glo-nacional da mídia. Mas uma discussão bo não leva alguma coisa ao ar, por exem-cotidiana, pois atualmente nós não plo. Ninguém se mobiliza, não sai nenhu- temos uma crítica de televisão, que ma notícia no jornal. Ou seja, censura é só quando o governo intervém, mas quando a própria emissora interfere em sua programação tirando coisas, mandando gente embora, ninguém fala nada. Há um processo de censura contínuo da própria rede com relação, por exemplo, a atitudes que seus empregados e criadores adotam em certos momentos. Há uma proposta na qual a sociedade constituiria uma comissão, ligada à Câmara, que definiria os limites da televisão e teria o poder legal de estabelecer sanções e eventualmente até de fechar emissoras ou redes, aplicar suspensões, etc. Esta comissão seria constituída por órgãos representativos da sociedade, não se sabe ainda quem, se o Congresso, o Judiciário ou representantes da área educativa. Eu não acho que este seja o caminho correto a se seguir. Este caminho legal é um caminho espinhoso, pois se a própria sociedade não está discutindo televisão, esta comissão não teria estofo intelectual para poder dizer o que a sociedade quer, não vai ter respaldo social.

$\mathrm{Eu}$ acho que a questão se refere à educação. Tudo deve começar nos níveis mais baixos de escolaridade. Nos E.U. A, por exemplo -eu sempre digo que a gente copia de lá só o que eles têm de pior, e não as coisas boas- existe uma disciplina, desde os primeiros anos de escolaridade, que se chama Educação para Mídia, que teria o fim de preparar as pessoas para ver televisão -e mídia, de uma forma geral-, criticar e eventualmente até produzir, porque a produção é também uma forma de se dar conta do que se pode e não se pode fazer. $\mathrm{Ou}$ seja, criar cidadãos em condições de ver, discriminar, discutir, ser capaz de dizer se - e por que - algo presta ou não, desde os primeiros anos de escolaridade. acompanhe os programas diariamente. Nós temos aqui, por exemplo, um curso de cinema que formou críticos, e um curso de rádio e TV que nunca formou críticos -aliás, nunca esteve em seus horizontes formar críticos, gente que intervém na imprensa e que produz um pensamento, uma reflexão sistemática sobre o meio. Muita gente vai ao cinema influenciado por opiniões, pelas críticas que lêem. Tem até aquelas estrelinhas que aparecem no jornal... Então, bem ou mal, o cinema é discutido e acompanhado. Há páginas e páginas nos jornais destinadas a isso. A discussão gerada em tomo do filme Cronicamente Inviável, por exemplo, foi impressionante. Não importa se o filme é bom ou não, mas a discussão que ele gerou é mais importante que o próprio filme. Ele fez aquilo que qualquer meio deveria fazer, que é gerar discussão, comoção, mobilização. Ele levanta temas e as pessoas enfrentam estes temas colocados, se colocam, rivalizam, se defrontam... Mas é assim que avançamos. No âmbito da televisão vemos pouco disso, e não é por que não temos programas instigantes. Eles existem, o que não existem são pessoas discutindo sobre eles. eTemos um Auto da Compadecida, por exemplo, que entra no ar e não gera nada: nenhuma crítica no jornal, nenhuma discussão, nenhum pensamento da 
Universidade a respeito, e aquilo morre, muito difícil, não fale mais que dois desaparece. Não aproveitamos coisas instigantes da televisão para desencadearmos uma discussão. minutos porque as pessoas páram de prestar atenção". A mentalidade criada a respeito do telespectador também é prejudicial. Às vezes eu imagino que as NO - Essa falta de discussão não estariapessoas que fazem televisão têm em ligada à nossa pouca prática da cida- mente o telespectador mais estúpido do dania, aos anos todos que ficamos mundo, e fazem o programa em função fechados na Ditadura? deste telespectador imaginário: um

AM - Eu acho que isto é também um fator, mas não preponderante. A sujeito não apenas desclassificado do ponto de vista intelectual, mas também sociedade brasileira é uma sociedade em despreocupado, que quer distração, que que a participação não existe, ela é difícil,não quer problemas, conflitos, ele quer tem poucos instrumentos, poucas instâncias. A divisão de classes também é muito rígida, muito difícil de ser quebrada. Mas há mobilização, posicionamento de grupos, vemos movimentos fortíssimos, como os Sem Terra, por exemplo. Eu não acho que a sociedade seja anestesiada. Eu acho que o problema é com o meio, e não com a sociedade. Ë como a sociedade se relaciona com o meio. Durante muito tempo nós encaramos a televisão como mero divertimento, um passatempo, uma coisa que fica na sala para distrair as crianças enquanto a mãe faz alguma tarefa. Sempre tivemos uma imagem empobrecedora da televisão, e isto é genérico, pois os próprios intelectuais e produtores de TV a vêem desta forma. Há um crescimento de uma certa mentalidade sobre a televisão difícil de mudar. O difícil é mudar o que a gente acha da TV.

Mas tem gente que acha outras coisas da televisão. Temos gente muito esperta, criadores fazendo trabalhos extraordinários dentro da televisão, que lutam com uma dificuldade tremenda contra essa mentalidade instalada. E esta mentalidade está instalada na cabeça do proprietário da $\mathrm{TV}$, do concessionário, de seus assessores mais imediatos e então todos os apenas relaxar. Precisamos saber como mudar esta mentalidade em todos os níveis, de crítica, de produção, de discussão.

\section{NO - Neste contexto, como você vê a questão da recepção?}

AM - Eu confesso que sempre tive muita dificuldade com a recepção, por uma deformação de constituição intelectual. $\mathrm{Na}$ nossa geração, quase todo mundo tem uma formação marxista originária, que é muito clara: numa sociedade capitalista, quem dá as regras é a produção, e não a recepção. No caso, a recepção seria algo equivalente ao consumo, e não é o consumidor que estabelece como deve ser o mercado. É a produção que impõe as necessidades, que condiciona o mercado. Então, quando invertemos e damos um peso ao receptor, damos a entender que o processo é contrário, que o receptor é quem vai determinar de que modo a televisão vai funcionar. Apesar disto, acho que a discussão sobre a recepção é importante, pois relativiza o peso excessivo que damos ao pólo produtor, como se não fossem as necessidades e os desejos das pessoas que impusessem certas soluções que se dão no nível da produção. Acho que hoje estamos em condições de pensar esta relação de uma trabalhadores, dos maiores aos menores, forma mais complexa. Antes, o que se a assumem como verdade. É incrível que pensava era que o produtor decide e não pode haver uma palavra mais difícil cria o mercado, cria o espectador. Aliás que eles já vêem dizer que o público não eu já vi umas declarações, acho que do vai entender esta palavra. "Não fale Boni, nos tempos áureos da Globo, que 
dizia que ele não estava interessado em saber o que o espectador quer, pois quem decide o que ele quer é quem produz. Como se através de uma produção constante de um programa pudesse ser criado um telespectador que goste do programa. É uma posição autoritária, arrogante.

A ênfase no pólo receptor trouxe dados novos a serem considerados, como: a televisão deve assumir temas que a sociedade está colocando, mesmo não querendo. Ela vai, cedo ou tarde, incorporar em novelas, jornais, seriados, temas que a sociedade impõe, para não ficar totalmente fora do que a sociedade está discutindo. Nenhum produtor resolveu por si colocar o tema dos Sem Terra na televisão, por exemplo.

Na verdade, é um jogo duplo: o pólo produtor realmente tem uma força, uma preponderância, mas ele não pode ser inteiramente refratário às exigências que vêm do pólo receptor. O que é a televisão? É resultado de forças muitas vezes contraditórias.

Acho que os estudos de recepção foram muito privilegiados com o surgimento de novas tecnologias, que recolocam de uma forma completamente nova o papel do receptor. As tecnologias interativas, que começam a dar um papel cada vez mais preponderante e ativo ao receptor, a ponto de hoje termos vários trabalhos em que não existe mais esta diferenciação produtor/receptor. A tendência hoje é criar trabalhos em aberto e que quem de fato vai fazer as coisas acontecerem é o receptor. Por isso eu até digo que o termo "receptor" está errado para os dias de hoje. A palavra receptor ainda trabalha na dicotomia velha, na qual alguém emite e alguém recebe. Precisámos de nomes novos para este novo agente, que está se impondo nos meios de comunicação.

NO - A passividade do espectador não estaria ligada exatamente à sua impotência tecnológica de reagir?

AM - Eu acho que isto é uma discussão histórica. Eu acho que nos falta este novo campo de pensamento que está surgindo sobretudo na Europa, que é a Arqueologia da Mídia. A falta de uma perspectiva histórica, às vezes, faz com que a gente pense que as coisas sempre foram como são agora. Uma coisa interessante de entendermos é que, até mais ou menos a década de 20 , essa separação não existia. E o rádio é, para mim, o meio mais importante para entendermos isso. $\mathrm{O}$ rádio sempre foi, durante todo seu surgimento até meados dos anos 30, um meio bidirecional e interativo. Todo o aparelho de rádio era receptor e emissor, o receptor de rádio é um aparelho que surgiu depois. Toda a pessoa que possuísse um aparelho de rádio tanto emitia quanto recebia informações. O rádio era então muito parecido com a Internet. Na verdade, há cem anos nós vivemos a experiência da Internet através do rádio. Cada pessoa que adquiria um rádio tinha que obter um prefixo, que funcionava como seu e-mail. Ela poderia, através dele, emitir e receber mensagens, além de poder sintonizar as emissoras de rádio comerciais e eventualmente também transmitir sua programação, como as pessoas que têm suas home pages na Internet.

O que aconteceu com o rádio, a partir de certo momento, é que a tecnologia foi cindida: o pólo receptor foi separado do pólo transmissor. Há uma discussão hoje se isto não irá acontecer com a Internet também. Há muita gente que o suspeita que a Internet vai deixar de ser o que ela é hoje, deixar de ter esta liberdade. Eu não acho que a história se repita necessariamente, mas é questão de nos posicionarmos em relação a isso. A única maneira de garantirmos que a liberdade na Internet jamais vai ser questionada é ocupá-la.

NO - O senhor não acha que a discussão sobre a qualidade dos programas de TV coincide, pelo menos em termos de intensidade, com a chegada da TV a 
cabo e com um tipo de programação quebsoluto, por que a Rede Globo tem um resgata o popular?

padrão de produção, tem uma marca, e

AM - Eu participava de um grupo na PUC-SP para discutir esta questão. A nossa primeira pesquisa era sobre o pensamento sobre TV no Brasil. Tentamos resgatar as pessoas que pensaram TV no Brasil, que escreveram e fizeram debate sobre ela. Percebemos que já nos anos 50 esta discussão existia, de uma forma muito intensa. Chegamos a levantar todo o trabalho de um jornalista dos anos 50, sobre a qualidade da televisão. Nos anos 60 , esta discussão voltou com os festivais de música popular — que, aliás, acho que é um dos grandes momentos da televisão brasileira, no qual ela estava totalmente integrada com a sociedade, era uma possibilidade de discussão política mediada pela discussão da música. Na verdade, não temos muita memória da História da Televisão, pois até pouco tempo não se estudava isto nas Universidades. Não há pesquisas, investigações sobre isto. Também pode ser questão de uso da palavra 'qualidade'. Nos anos 50, se fala muito em 'estética' da televisão. Ela era então encarada como um meio novo, tão importante quanto o cinema, mas com outra estética, outra linguagem, a serem investigadas.

\section{NO - Como o senhor vê a questão da programação televisiva no Brasil?}

AM - Eu acho que a televisão demanda uma série de mudanças em nível legal, nunca vai ter diversidade lá dentro, e a Rede Globo é intocável nisso. É ela a que mais bate o pé dizendo que não pode haver ingerência externa. Deveria haver um processo legislatório que determinasse que uma televisão não pode pôr mais que $20 \%$ de programação no ar produzida por ela própria, que em geral são os programas jornalísticos, os debates. O resto da programação tem que ser comprada dos produtores independentes, isso geraria uma demanda gigantesca de produção de televisão, criaria emprego para toda essa moçada que está saindo dos cursos de televisão, que estariam criando propostas para ela. Até nos EUA é assim, não sei qual é a porcentagem de programação própria, mas é muito pequena.

Outra coisa é a regionalização. As televisões locais simplesmente põem no ar a Globo, a Manchete, o SBT, não têm produção própria, a não ser aquele jornal local... é insignificante. Também deveria ter uma legislação que estabelecesse um limite de programação em rede nacional. Isso estimularia a produção própria da região, geraria emprego, a cultura local seria estimulada, em vez dessa chamada "integração nacional" que a televisão diz ter.

Isso sem falar na própria possibilidade de abertura de canais, coisas que a gente quase não tem aqui, como canais de que aqui nunca existiram e que em outros acesso público, canais experimentais. países já existem, que vão de certa forma Nós não temos aqui coisa que tem em permitir o florescimento de divergência, alguns países europeus, que são instide novas propostas de programação. tuições estatais, como a FAPESP, que Por exemplo, a televisão não pode financiam projetos de criação de produzir a sua própria programação. Tem programas experimentais, de pilotos de que haver um limite pra isso. A rede de TV é um sistema de distribuição, mas ela própria não pode pôr no ar o que ela mesmo faz, tem que ter um limite para isso. Na Rede Globo, hoje, tudo o que vai para o ar é a própria Rede Globo que faz. O que não é ela que faz, ela compra dos Estados Unidos. Isso cria um vício programas de televisão. A gente tem quatro ou cinco famílias que passaram por toda a tradição autoritária da ditadura, que dominam completamente o mercado de televisão no país. Não há diversidade, e a qualidade é conseqüência da diversidade. Não dá para pensar uma televisão diferente com essa 
estrutura que nós temos. As televisões têm privilégios hoje que são coisas impressionantes. Por que a Rede Globo está sempre equipada com as tecnologias mais recentes? Ela vai ao Japão e compra as tecnologias mais recentes, e não pagam imposto nenhum. Não paga nada. As televisões estão isentas, mas qualquer produtora independente que compra uma câmera e paga impostos pesadíssimos.

As emissoras não pagam imposto também. Em muitos lugares existe um imposto sobre as telecomunicações, as emissoras deveriam pagar um imposto específico para poder estar utilizando esse privilégio que é o direito de usar o ar e ir para a casa das pessoas. Com esse imposto é que você financia, por exemplo, projetos experimentais na área de inovação em televisão. O Channel 4 é sustentado pelo imposto pago pelas outras emissoras. A gente não tem nada disso, há uma dominação absoluta que não é nem sobre TV, mas sobre a mídia, porque são grupos que dominam também a imprensa, o rádio, o mercado de discos.

NO - Qual o papel da Universidade na discussão sobre o lugar social da televisão?

AM - Ela não tem cumprido seu papel, pelo menos não em relação à televisão. É só ir à biblioteca e ver a produção de pensamento sobre televisão, pelo menos a nossa é muito pequena. Tem crescido nos últimos tempos, mas ainda é muito pequena. Se não formos nós, quem vai ser? É difícil imaginar que outros setores da Universidade tenham mais autonomia ou mais meios, instrumental, para propor essa política ou pelo menos para desencadear essa discussão. Também não acho que uma discussão desse tipo tenha que ficar fechada dentro dos muros da Universidade, mas o desencadeamento dessa discussão deveria partir daqui. Eu acho que a Universidade está perdendo bastante o bonde da história, em muitas questões. Dentro da Universidade está todo mundo correndo atrás de seu salário, são problemas tão pequenos que perdemos a capacidade de intervir no debate e, mais ainda, de criar temas para discussão. Ainda nos anos 60, quando comecei a despertar para a vida intelectual, eram os intelectuais que davam o tom da discussão. Paulo Emílio, Antônio Cândido, os grandes intelectuais colocavam: "a discussão agora é essa", e aí todo mundo vinha e discutia o que eles colocavam. Hoje quem coloca a discussão é a Folha de São Paulo. É impressionante, você entra na Universidade e está todo mundo comentando o que foi colcado na Folha de São Paulo. É a Folha de São Paulo que decide? É ela que dá os temas e a gente vai correndo atrás deles para tentar dar respostas às questões? Às vezes eu me recuso a responder certas questões, parece presunção, mas é que a gente não tem que ficar dando respostas a temas que não interessam à gente. Temos que criar nossos temas, inicialmente nos nossos parcos recursos, nas revistas que temos, nos meios que temos acesso. O que não dá é ficar atrás de uma discussão que a imprensa e a própria TV colocam. 


\section{Bibliografia do entrevistado}

MACHADO, Arlindo A arte do vídeo. Brasiliense, São Paulo, 1988.

MACHADO, Arlindo. Máquina e imaginário: o desafio das poétcas tecnológicas. Edusp, São Paulo, 1993.

MACHADO, Arlindo. Pré-cinemas \& Pós-cinemas. Papirus, Capinas, 1997

MACHADO, Arlindo. Os primórdios do cinema (1895-1926). Agência Observatório, São Paulo, 1997.

MACHADO, Arlindo. El Paisaje Mediático. Libros de Rojas, Buenos Aires, 2000.

MACHADO, Arlindo. A televisão levada a sério. Ed. SENAC, São Paulo, 2000. 